
МЕТОДИКИ ВИКОРИСТАННЯ ЗАСОБІВ ЗМІШАНИХ БОЙОВИХ МИСТЕЦТВ
У ПРОЦЕСІ ФІЗИЧНОГО ВИХОВАННЯ ПІДЛІТКІВ 15-16 РОКІВ

\title{
METHODOLOGIES OF THE USE OF FACILITIES OF THE MIXED MARTIAL ARTS IN THE PROCESS OF PHYSICAL EDUCATION OF TEENAGERS 15-16 YEARS
}

\begin{abstract}
у статті показано доцільність використання розробленої методики змішаних бойових мистецтв щодо формування основних фрізичних якостей старших школярів, підвищення інтересу до уроків фрізичної культури в школі, сприяння стійкої мотивації до занять спортом шляхом упровадження в навчально-тренувальний процес школярів 15-16 років специфрічних підготовчих вправ. Також було розроблено методики використання прийомів, спрямованих на перемогу в поєдинку, але намагались уникнути прийомів, спрямованих на знищення або травмування противника. Такий спортивний варіант охоплював техніку нанесення ударів і захистів і техніку прийомів боротьби. Удари були представлені поєднаними прийомами з боксу, кікбоксингу, тайського боксу, тхеквондо, ушу й карате. Прийоми боротьби були представлені поєднаними прийомами з вільної боротьби, самбо, дзюдо й окремого розділу захоплень, заломів і звільнення від захоплень з китайського цигуна і японського джиу-джитсу. Важливим чинником була робота над збільшенням м'язової маси для розвитку вибухової сили, яка вкрай важлива під час протистояння перед напором і вагою супротивника. Саме тому ми залучили до своєї програми підготовки елементи важкої атлетики, зокрема роботу зі штангою. Учні використовували штангу вагою від 20 кг.
\end{abstract}

3 метою виявлення есрективності впливу методики навчання специорічним технічним діям змішаних бойових мистецтв на фрормування фрізичних і фрункціональних показників у школярів 15-16 років протягом навчального року (10 місячів) було проведено педагогічний експеримент. На базі загальноосвітньої школи I-III ступеня № 20, м. Одеса, був проведений педагогічний експеримент. У ньому взяли участь 34 юнаки 15-16 років, учні 10-11-х класів, які мали приблизно однакові фрізичні й фрізіологічні характеристики та не мали медичних обмежень до занять змішаними єдиноборствами.

Було здійснено попереднє вивчення стану фрізичної підготовленості, фуннкціонального стану, а також проведення антропометричних вимірювань. Також дослідним шляхом було перевірено ефрективність адаптованої методики навчання специорічним технічним діям змішаних бойових мистецтв (далі - ММА) школярів 15-16 років.
Ключові слова: змішані бойові мистецтва, фрізична культура, фрізичний розвиток, юнаки.

In the article expediency of the use of worked out is shown methodology of the mixed martial arts in relation to forming of basic physical internals of high scool students, increase of interest in the lessons of physical culture at school, assistance of proof motivation to going in for sports due to introduction in the educational training process of schoolchildren 15-16 y. o. specific preparatory exercises. Methodologies of the use of the receptions sent to victory in a duel were also considered, and tried to avoid the receptions sent to elimination or injuring of opponent. Such sporting variant included for itself the technique of inflicting blows and protect and technique of receptions of fight. Shots were presented by the incorporated receptions from boxing, to the kickboxing, thai boxing, taekwondo,wushu and karate. The receptions of fight were presented by the incorporated receptions from a free fight, sambo, judo and separate division of clinch, twisting and release from clinch from china qigong and japanese jiu jitsu. An important factor was a prosecution of increase of muscular mass for development of explosive force that is extremely important during opposition before pressure and weighing opponent. For this reason we involved the elements of weightlifting in the program of preparation, in particular work with a barbell.Students used a barbell weight from $20 \mathrm{~kg}$. With the target of exposure of efficiency of influence of methodology of studies to the specific technical actions of the mixed martial arts on forming of physical and functional indexes for schoolchildren 15-16 y. o. during a school year (10months) a pedagogical experiment was conducted. On the base of general school I-III of degree № 20, Odesa, a pedagogical experiment was conducted. In him participated 34 boys 15-16 y. o. are students 10-11 classes that had approximately identical physical and physiology descriptions and did not have medical limitations to engaging in the mixed martial arts. The previous study of the state was carried out physical preparedness, functional state, and also realization of the anthropometric measuring. Also the effectiveness of the adapted method of teaching specific technical actions of the MMA students of 15-16 years was verified by the experimental method.

Key words: martialarts, physical culture, physical development, boys педагогічного університету імені К.Д. Ушинського

Постановка проблеми в загальному вигляді. Змішані бойові мистецтва викликають величезний інтерес підлітків до занять у цьому виді спорту. Можна констатувати, що цей вид єдиноборств не отримав належного поширення в освітніх установах. У більшості шкіл відсутні фрахівці зі змішаних бойових мистецтв, дуже мало наукових розробок, методик і програм з цього виду спорту.

Сьогодні реформування фрізкультурної освіти передбачає більшу свободу для вчителів фрізич- ної культури й для учнів під час обрання найбільш ефрективних фрорм і методів фрізичного виховання. Внаслідок пріоритету «змішаного» стилю ведення поєдинку, гуманізації правил ММА і великого інтересу підлітків до занять бойовими мистецтвами, доцільно ввести засоби ММА в процес фрізичного виховання в старших класах для підвищення мотивації та бажання займатися спортивною діяльністю.

Однак це викликає певні труднощі. Практика показує $[3,6,8]$, що методика підготовки дорослих 
спортсменів не підходить для дітей і юнаків 3 двох причин: діти та юнаки мають свої вікові особливості, які необхідно враховувати під час занять спортом; найчастіше дорослі спортсмени приходять у рукопашний бій уже сорормованими спортсменами. Заняття ж 3 дітьми й підлітками доводиться починати практично з нуля, що, безсумнівно, накладає свій відбиток на методику й програму підготовки.

У зв'язку 3 вищевикладеним постає низка питань, з якими у своїй практиці стикається практично кожен тренер у будь-якому з видів змішаних бойових мистецтв: які технічні дії 3 арсеналу різних видів спортивних єдиноборств варто включати в програму підготовки юнаків; як найбільш есрективно, доцільно й послідовно вибудувати методику навчання різним техніко-тактичним діям змішаних бойових мистецтв. Це далеко не повний перелік питань, на які необхідно відповісти фрахівцям ММА для того, щоб такі єдиноборства отримали подальший розвиток і набули більшої популярності серед українців.

Ми припустили, що адаптована методика навчання специфічним технічним діям MMA швидше сорормує основні фрізичні якості старших школярів, підвищить інтерес до уроків фрізичної культури в школі, сприятиме стійкій мотивації до занять спортом через упровадження в навчальнотренувальний процес школярів 15-16 років специфрічних підготовчих вправ.

Мета статті - обґрунтування адаптованої методики навчання специфічним технічним діям ММА підлітків 15-16 років. На основі аналізу літературних джерел розглянути загальну характеристику процесу навчання технічним діям в єдиноборствах, розглянути техніку в ММА і виявити специфрічні технічні дії. Адаптувати методику навчання специфічним технічним діям ММА для школярів 15-16 років, дослідним шляхом перевірити ефективність адаптованої методики навчання специфрічним технічним діям ММА школярів 15-16 років.

Виклад основного матеріалу. Теоретична значущість дослідження полягає в науковому обґрунтуванні доцільності застосування засобів змішаних бойових мистецтв у практиці фрізичного виховання 3 метою оздоровлення, збільшення рухової активності, підвищення показників фрізичної підготовленості підлітків 15-16 років. Ця методика дасть можливість учителям фрізичної культури застосовувати розроблений комплекс вправ у навчально-тренувальному процесі з підлітками 15-16 років. А також буде корисна тренерам з таких видів спорту: кікбоксинг (фулконтакт, лоукік і К-1), рукопашний бій, кудо, змішані єдиноборства (M-1, UFC, PRIDE).

Змішані бойові мистецтва останнім часом стають усе популярнішими в Україні, хоча ще досить часто можна зустріти абсолютно помилкове судження, що це бої без правил. Насправді ж це високоінтенсивне бойове мистецтво, яке поєднує в собі техніки й прийоми різних єдиноборств, таких як бокс, кікбоксинг, тайський бокс і карате тощо [3]. Саме тому підготовка підлітків вимагає грамотного підходу і різноманітності методик тренувань.

Аналізуючи ситуацію, що склалася сьогодні в системі підготовки спортсменів у змішаних бойових мистецтвах, можна помітити таке:

- істотно збільшується кількість спортивних секцій, військово-патріотичних і спортивних клубів, котрі культивують різні види єдиноборств [3];

- змішані бойові мистецтва набули неабиякої популярності, але багато аспектів, а також проблеми управління тренувальним процесом вивчені недостатньо, особливо це можна сказати про підготовку дітей та юнаків [6];

- у змішаних бойових мистецтвах на сьогодні немає єдиної термінології, існують суперечності в назвах технічних дій і прийомів [1];

- у підготовці юнаків тренерам доводиться використовувати методику передзмагання дорослих спортсменів або методику інших видів єдиноборств [2].

Усе це призводить до уповільнення прогресу або взагалі до його відсутності в тренуваннях спортсменів, а іноді й до порушень їхнього фрізичного розвитку.

У нашій методиці ми використовували прийоми, спрямовані на перемогу в поєдинку, і намагались уникнути прийомів, спрямованих на знищення або травмування противника. Такий спортивний варіант містив техніку нанесення ударів і захистів і техніку прийомів боротьби.

Удари були представлені поєднаними прийомами боксу, кікбоксингу, тайського боксу, тхеквондо, ушу й карате. Прийоми боротьби були представлені поєднаними прийомами вільної боротьби, самбо, дзюдо й окремого розділу захоплень, заломів і звільнення від захоплень з китайського цигуна і японського джиу-джитсу. Важливим фрактором була робота над збільшенням м'язової маси для розвитку вибухової сили, яка вкрай важлива у протистоянні перед напором і вагою супротивника. Саме тому ми залучили до своєї програми підготовки елементи важкої атлетики, зокрема роботу зі штангою. Учні використовували штангу вагою від 20 кг.

3 метою виявлення есрективності впливу методики навчання специфічним технічним діям змішаних бойових мистецтв на фрормування фрізичних і функціональних показників у школярів 15-16 років протягом навчального року (10 місяців) на базі загальноосвітньої школи I-III ступеня № 20, м. Одеса, було проведено педагогічний експеримент. У ньому взяли участь 34 юнаки 15-16 років учні 10-11-х класів, які мали приблизно однакові фрізичні й фрізіологічні характеристики та не мали медичних обмежень до занять змішаними єдиноборствами. 
Було здійснено попереднє вивчення стану фрізичної підготовленості, фрункціонального стану, а також проведення антропометричних вимірювань.

Випробовуваних за бажанням розділили на дві групи. Експериментальна група (далі - ЕГ) складалася 312 юнаків, які бажали займатися змішаними бойовими мистецтвами. До контрольної групи (далі - КГ) увійшла та ж кількість юнаків (n = 12), які виявили бажання відвідувати заняття за програмою загальної фрізичної підготовки 3 силовою спрямованістю.

Дві групи учнів окрім обов'язкових уроків фрізичної культури відвідували додатково щотижня три заняття тривалістю 60 хвилин кожне.

Ефективність обраної методики доведено експериментальним шляхом. Після систематичних занять був проведений аналіз кінцевих результатів, який показав, що юнаки ЕГ випереджають по всіх показниках фрізичних якостей юнаків КГ, які відвідували додаткові заняття силової спрямованості (табл. 1).

Так, за швидкістю в ЕГ результат на 7,6\% кращий, ніж у КГ; за спритністю - на 3,0\%, за динамічною силою м'язів ніг - на 3,8\%, за загальною витривалістю - на 5,6\%.
Найбільші відмінності в результатах виявилися під час тестування гнучкості й силової витривалості: в ЕГ показники кращі, ніж у КГ, на 33,6\% і 35,7\% відповідно.

Позитивні зміни у фрункціональному стані підлітків ЕГ найбільш яскраво демонструють збільшення життєвої ємності легень, стабілізація артеріального тиску (на початку в середньому 128/ 78, наприкінці - 120/80).

Суттєві зміни зафріксовані в показниках «ортостатична проба» й «кількість простудних захворювань за навчальний рік» ( $p<0,01)$. Це означає, що експериментальна методика значно поліпшила фрункціонування серцево-судинної й нервової систем, стабілізувала фрункцію симпатичного відділу вегетативної нервової системи й значно підвищила опірність організму до захворювань. За час проведення експерименту в юнаків, які відвідували заняття силової спрямованості, також підвищилась опірність організму до простудних захворювань, однак у решті зміни були незначні (табл. 2).

Висновки. Таким чином, розроблена експериментальна методика в системі фрізичного виховання у школярів ЕГ, що займаються змішаними бойовими мистецтвами в позаурочний час, дала такі позитивні результати:

Таблиця 1

Показники фрізичної підготовленості ЕГ і КГ наприкінці експерименту

\begin{tabular}{|c|c|c|c|c|}
\hline \multirow{2}{*}{ Рухові тести } & $\mathrm{E \Gamma}(n=12)$ & $K \Gamma(n=12)$ & \multirow{2}{*}{ p } & \multirow{2}{*}{ Різниця \% } \\
\hline & $\mathrm{M} \pm \mathrm{T}$ & $\mathrm{M} \pm \mathrm{T}$ & & \\
\hline Біг $30 \mathrm{~m}, \mathrm{c}$ & $4,98 \pm 0,05$ & $5,36 \pm 0,05$ & $<0,05$ & 7,6 \\
\hline Човниковий біг $3 \times 10$, с & $8,72 \pm 0,08$ & $8,98 \pm 0,09$ & $>0,05$ & 3,0 \\
\hline Стрибки в довжину з місця, см & $205,29 \pm 3,23$ & $197,71 \pm 2,97$ & $<0,05$ & 3,8 \\
\hline 6-хвилинний біг, м & $1194,29 \pm 18,04$ & $1131,43 \pm 15,39$ & $<0,05$ & 5,6 \\
\hline Нахил вперед з положення сидячи, см & $7,83 \pm 0,43$ & $5,86 \pm 0,45$ & $<0,05$ & 33,6 \\
\hline Підтягування, кільк. разів & $10,0 \pm 1,43$ & $7,37 \pm 0,49$ & $<0,05$ & 35,7 \\
\hline
\end{tabular}

Таблиця 2

Показники фуунцціонального стану підлітків 15-16 в ЕГ і КГ до і після експерименту, М土т

\begin{tabular}{|c|c|c|c|c|}
\hline Функціональні показники & Група & $\begin{array}{c}\text { На початку експерименту } \\
(\mathrm{M} \pm \mathrm{T})\end{array}$ & 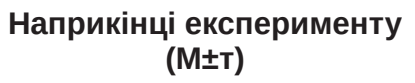 & $\mathbf{p}$ \\
\hline \multirow{2}{*}{ ЖєЛ, мл } & EГ & $364 \pm 0,06$ & $398 \pm 0,06$ & $<0,05$ \\
\hline & КГ & $3,52 \pm 0,07$ & $3,54 \pm 0,07$ & $>0,05$ \\
\hline \multirow{2}{*}{ Ортостатична проба, чСС } & $\mathrm{E \Gamma}$ & $16,37 \pm 0,56$ & $10,48 \pm 0,46$ & $<0,01$ \\
\hline & $\mathrm{K} \Gamma$ & $15,80 \pm 0,72$ & $16,23 \pm 0,33$ & $>0,05$ \\
\hline \multirow{2}{*}{ АТ систолічний, мм рт. ст. } & EГ & $128,43 \pm 0,91$ & $120,14 \pm 0,53$ & $<0,05$ \\
\hline & КГ & $124,57 \pm 1,16$ & $130,14 \pm 0,78$ & $<0,05$ \\
\hline \multirow{2}{*}{ АТ діастолічний, мм рт. ст. } & EГ & $78,14 \pm 0,88$ & $80,85 \pm 0,62$ & $<0,05$ \\
\hline & КГ & $76,71 \pm 1,30$ & $82,0 \pm 0,85$ & $<0,05$ \\
\hline \multirow{2}{*}{ Довжина тіла, см } & $\mathrm{E} \Gamma$ & $172,57 \pm 0,78$ & $174,42 \pm 0,79$ & $>0,05$ \\
\hline & $\mathrm{K \Gamma}$ & $171,60 \pm 1,05$ & $173,40 \pm 1,02$ & $<0,05$ \\
\hline \multirow{2}{*}{ Маса тіла, кг } & EГ & $61,83 \pm 0,74$ & $62,91 \pm 1,04$ & $>0,05$ \\
\hline & КГ & $61,20 \pm 1,25$ & $63,71 \pm 1,13$ & $<0,05$ \\
\hline \multirow{2}{*}{$\begin{array}{c}\text { Пропуски занять через хворобу, } \\
\text { кільк. за навч. рік }\end{array}$} & $\mathrm{E} \Gamma$ & $2,91 \pm 0,08$ & $1,57 \pm 0,08$ & $<0,01$ \\
\hline & КГ & $2,86 \pm 0,09$ & $1,54 \pm 0,09$ & $<0,01$ \\
\hline
\end{tabular}


- комплексний розвиток фрізичних якостей, поліпшення показників фрункціонального стану;

- уміння школярів використовувати засоби ММА для зміцнення здоров'я;

- формування навичок єдиноборства завдяки здобутому на тренуваннях досвіду жорстких контактних поєдинків;

- вміння здійснювати самозахист в непередбачених життєвих ситуаціях;

- залучення учнів до фрізичного й морального виховання, здорового способу життя, загартовуванню організму, організації правильного режиму праці й відпочинку;

- здатність переносити великі фрізичні й психологічні навантаження;

- розуміння необхідності вимог дисципліни й підготовленість до проходження військової та іншої державної служби.

Висновки. Змішані бойові мистецтва мають певну специсріку формування фрізичної культури підлітків 15-16 років й ефективні за умови залучення до тренувального процесу методичних матеріалів. Систематичні й регулярні заняття за розробленою методикою сприяють значним позитивним змінам в особистості школярів.

\section{БІБЛІОГРАФІЧНИЙ СПИСОК:}

1. Ашкинази С.М. Результаты экспериментального исследования методики развития специальных фризических качеств спортсменов, занимающихся смешанными единоборствами /С.М. Ашкинази. Актуальные проблемы фризической и специальной подготовки силовых структур. 2016. № 1. С. 118-128.

2. Бавыкин Е.А. Сравнительный анализ средств специальной фризической подготовки в различных видах единоборств / Бавыкин Е. А. Роль и место информационных технологий в современной науке. 2016. № 1. C. 167-171.

3. Кузьмин В.А. Проблемы и перспективы развития спортивных смешанных боевых единоборств в высших учебных заведениях/В.А. Кузьмин, К.В. Гатилов, М.Д. Кудрявцев. Єдиноборства. 2016. С. 35-39.

4. Кукушкін К. Хортинг як система вдосконалення особистості, як фрілософрія і спосіб життя / К. Кукушкін. Теорія і методика хортингу. 2014. № 1. С. 75-81.

5. Приказ № 633 «О развитии борьбы вольного стиля» от 16 ноября 1938 г. - [Режим доступу] - http:// dictionnaire.sensagent.leparisien.fr/Mixed-martial\%20 arts/en-en/ (дата звернення 17.08.2019).

6. Санжарова Н.М. Теорія і методика викладання спортивних єдиноборств у системі підготовки майбутніх учителів фізичної культури / Н.М. Санжарова та ін. Єдиноборства. 2017. С. 57-60. 